\title{
Antibiosis and Acidification by Pantoea agglomerans Strain E325 May Contribute to Suppression of Erwinia amylovora
}

\author{
P. L. Pusey, V. O. Stockwell, and D. R. Rudell
}

First and third authors: U.S. Department of Agriculture-Agricultural Research Service, Tree Fruit Research Laboratory, Wenatchee, WA 98801; and second author: Department of Botany and Plant Pathology, Oregon State University, Corvallis 97330. Accepted for publication 1 July 2008.

\section{ABSTRACT}

Pusey, P. L., Stockwell, V. O., and Rudell, D. R. 2008. Antibiosis and acidification by Pantoea agglomerans strain E325 may contribute to suppression of Erwinia amylovora. Phytopathology 98:1136-1143.

Pantoea agglomerans strain E325, a commercially available antagonist for fire blight of apple and pear, was originally selected through screening based on suppression of Erwinia amylovora on flower stigmas, but specific mechanisms of antagonism were unknown. Bacterial modification of $\mathrm{pH}$ was evaluated as a possible mechanism by analyzing stigma exudates extracted from 'Gala' apple stigmas. The $\mathrm{pH}$ values for field samples were only slightly lower than controls, but indicated a range $(\mathrm{pH}$ 5 to 6) conducive for antibiotic activity according to subsequent assays. Under low-phosphate and low-pH conditions, an antibacterial product of E325 with high specificity to E. amylovora was effective at low concen- trations. A minimum of 20 to $40 \mathrm{ng}$ of a ninhydrin-reactive compound purified using RP-HPLC caused visible inhibition in assays. Activity was heat stable and unaffected by amino acids, iron, or enzymes known to affect antibiotics of $P$. agglomerans. Antibiosis was diminished, however, under basic conditions, and with increasing phosphate concentrations at pH 6 and 7. Inhibition was not observed in media containing phosphate concentrations commonly used in antibiosis assays. We propose that E325 suppresses the fire blight pathogen not only by competing for nutrients on the stigma, but by producing an antibiotic specific to $E$. amylovora. Further work is necessary to substantiate that the compound is produced and active on flower stigmas.

Additional keywords: Malus pumila.
Fire blight, a major disease of apple and pear trees, is most commonly initiated by epiphytic populations of Erwinia amylovora residing on blossoms $(42,44)$. Under dry climatic conditions, bacteria colonize flower stigmas, and subsequent rain or heavy dew facilitates movement to the floral cup (hypanthium) where infection generally occurs (41). Management programs have emphasized risk assessment (6) and suppression of E. amylovora on floral parts with antibiotics (34). The reliance on streptomycin, in particular, led to the development of pathogen resistance in many production areas $(24,26)$.

Suppression of E. amylovora on flowers with microbial antagonists is a viable alternative $(16,17)$ or complementary measure to antibiotics $(23,39)$. In 1996 Pseudomonas fluorescens strain A506, initially selected based on its inhibition of an icenucleating strain of $P$. syringae on corn leaves (22), became the first commercially available antagonist for fire blight management (BlightBan A506; Nufarm Americas Inc., Burr Ridge, IL) (16). Products consisting of strains of Pantoea agglomerans (syn. E. herbicola) include one in commercial use in New Zealand since 2001 (45) and two others recently approved in North America $(8,9,37)$.

Methods used for screening and selection of microbial antagonists of E. amylovora have evolved from the use of artificial media $(3,38)$ to laboratory procedures with immature pear fruit $(4,47,52)$ and later to bioassays involving detached flowers $(27,29)$. Media- and fruit-based assays have been useful for identifying and studying antagonist strains that produce anti-

Corresponding author: P. L. Pusey; E-mail address: larry.pusey@ars.usda.gov

doi:10.1094/PHYTO-98-10-1136

This article is in the public domain and not copyrightable. It may be freely reprinted with customary crediting of the source. The American Phytopathological Society, 2008. biotics inhibitory to E. amylovora, but results often do not correlate with suppression of the pathogen on blossoms $(48,49)$. Direct evaluation of microbial strains on flowers, though more labor intensive than other methods, is more likely to identify antagonists effective on floral surfaces $(2,17)$.

The selection of $P$. agglomerans strain E325, the active ingredient in Bloomtime Biological (Northwest Agricultural Products, Pasco, WA), was selected from more than 1,000 isolates of bacteria and yeasts collected from apple and pear blossoms and evaluated on flowers for potential use in fire blight management (P. L. Pusey, unpublished data [30]). In screening assays with detached crab apple blossoms (29), strain E325 showed exceptional suppressive activity toward E. amylovora on stigmatic surfaces and later proved effective in reducing blossom blight on mature apple trees (31). Like other microbial strains studied (17), E325 is an excellent colonizer of the stigma $(31,32)$ and likely competes with the pathogen for space and nutrients. Given its high efficacy on flowers, we suspected antibiotic production as another mechanism of antagonism, but detection was elusive. When testing for antibiosis using methods and media of other researchers, inhibition zones either did not appear, or their appearance could not be reproduced in assays. To investigate mechanisms of strain E325 and other antagonists on flower stigmas, stigma exudates from pomaceous flowers were chemically analyzed (33), and free sugars and amino acids detected in these analyses were incorporated into a partial stigma-based medium (PSBM). The phosphate-buffer concentration in PSBM was relatively low, and suppression of E. amylovora by strain E325 was correlated with acidification of the medium and the presence of inhibition zones on solid PSBM (unpublished data).

Early fire blight researchers proposed that bacteria fitting the description of P. agglomerans inhibited E. amylovora on apple and pear trees in the orchard environment by producing acid $(11,12)$, and Riggle and Klos (35) suggested the acidification 
occurs on blossoms. Wodzinski et al. (51) found that strains of $P$. agglomerans differing in ability to protect pear fruit from infection by E. amylovora did not cause a corresponding effect on $\mathrm{pH}$ in fruit tissue or in a complex medium, and thus, concluded that acid production is an unlikely mechanism of inhibition in planta. At present, the most important mechanisms of antagonism on blossoms are thought to be competitive exclusion and antibiotic production $(17,43)$.

The following describes recent efforts to evaluate $\mathrm{pH}$ changes on flower stigmas inoculated with strain E325, and to partially characterize an inhibitory product of this antagonist active against E. amylovora under low-phosphate and low-pH conditions.

\section{MATERIALS AND METHODS}

Bacterial strains. P. agglomerans strain E325 was isolated from 'Gala' apple blossoms near Wenatchee, WA, in 1994 (29). The primary pathogen used was E. amylovora strain Ea153, obtained from K. Johnson (Oregon State University, Corvallis). It was originally isolated from cankers of Gala apple in Oregon and later used in studies with apple and pear $(18,19)$. Both antagonist and pathogen are spontaneous antibiotic-resistant derivatives generated at the source laboratories. Strain E325 is resistant to rifampicin and streptomycin, and strain Ea153 is resistant to nalidixic acid. Original strain codes (i.e., without added letters indicating specific derivatives) are used in this article. Other bacteria were used to test the activity spectrum of an antibiotic product of E325. Those that lacked established identification in the literature, were identified to species by at least two methods: (i) fatty acid methyl ester analysis with the Microbial Identification System (Microbial ID, Inc., Newark, DE) and (ii) $16 \mathrm{~S}$ rRNA gene sequence analysis (1). The latter method involved reaction conditions described by Tewoldemedhin et al. (40), analysis with a CEQ 8000 Genetic Analysis System (Beckman Coulter, Fullerton, CA), and BLAST searches on GenBank.

Bacteria were generally stored on silica gel at $-20^{\circ} \mathrm{C}$ (36) and cultured initially on nutrient yeast dextrose agar (NYDA; $8 \mathrm{~g}$ of nutrient broth, $5 \mathrm{~g}$ of yeast extract, $5 \mathrm{~g}$ of dextrose, and $15 \mathrm{~g}$ of agar in 1 liter of deionized water) for $24 \mathrm{~h}$ at $24^{\circ} \mathrm{C}$. Cell suspensions were prepared from these cultures for inoculating flower stigmas or an agar medium used for producing and detecting the E325 antibiotic. For stigma inoculations, suspensions were adjusted to 0.1 optical density at $600 \mathrm{~nm}$ using a spectrophotometer (Spectronic 20; Milton Roy Co., Rochester NY) to approximate a cell density of $1 \times 10^{8}$ colony forming units $(\mathrm{CFU}) / \mathrm{ml}$. This concentration or a one-tenth dilution was used in the experiments.

Evaluation of $\mathbf{p H}$ on inoculated stigmas. To study the effect of $P$. agglomerans E325 on the $\mathrm{pH}$ of blossom stigmas, exudates were extracted from inoculated stigmas of Gala apple (Malus pumila) and evaluated for $\mathrm{pH}$. On three dates in 2005 (26, 27, and 28 April), 150 newly opened flowers were detached from trees located in a research orchard at Columbia View, north of Wenatchee, WA. The cut end of each flower pedicle was submerged in $10 \%$ sucrose contained in a $2-\mathrm{ml}$ vial (29). Holding vials were supported in plastic tube racks inside 4-liter plastic containers, which were transported to the laboratory. One group of 50 flowers was inoculated on stigmas with E325 by applying 1 to $2 \mu \mathrm{l}$ of suspension $\left(10^{8} \mathrm{CFU} / \mathrm{ml}\right.$ in $0.03 \%$ Tween-20 and $0.01 \mathrm{M}$ phosphate buffer, $\mathrm{pH}$ 7) per flower by touching a droplet to each stigma (normally five per flower) to form a thin film of moisture. A second group of 50 was likewise inoculated with E. amylovora Ea153, and the third group was not inoculated. After $24 \mathrm{~h}$ at $24^{\circ} \mathrm{C}$ and $90 \%$ relative humidity, petals and anthers were removed, and stigma tips of each group of 50 flowers were submerged, one flower at a time, in $600 \mu \mathrm{l}$ of water in a microfuge tube, while sonicated for $10 \mathrm{~s}$ per flower. Pollen, debris, and microorganisms were removed from the aqueous solution by centrifugation at $16,000 \times g$ for 5 min and by subsequent filtration of supernatant in syringe-driven unit with polyvinylidene difluoride (PVDF) membrane, 4-mm diameter and $0.22-\mu \mathrm{m}$ pore size (Millex-GV; Millipore Corp., Billerica, MA). The $\mathrm{pH}$ was measured in each $600-\mu \mathrm{l}$ sample representing 50 flowers. To evaluate $\mathrm{pH}$ in exudate concentrations more comparable to those in situ, samples were dried in a vacuum evaporator and redissolved in reduced volumes of water to increase concentrations by 10 and $50 \times$. The $\mathrm{pH}$ in these low volumes (60 and $12 \mu \mathrm{l})$ was measured with an Accumet AP63 pH meter (Fisher Scientific, Pittsburgh, PA) using electrodes designed for use in a minimum liquid depth of $3 \mathrm{~mm}$ (Accumet Combination MicroProbe, 13620-96; Fisher Scientific) or $1 \mathrm{~mm}$ (Orion 98-10, Micro-Combination Electrode; Thermo Electron Corp., Beverly, MA).

To evaluate whether bacteria alter stigma $\mathrm{pH}$ in the field, an experiment was conducted with Gala apple at Columbia View in 2006 and 2007. Branches were tagged for use, and new flowers were isolated by removing all opened flowers on 1 day and removing all unopened flowers the following day, leaving a minimum of 120 new flowers per tree. Inoculations were made on two dates, i.e., when flowers were newly opened and 2 days later (27 and 29 April 2006; 24 and 26 April 2007), by applying suspensions of $P$. agglomerans $\mathrm{E} 325\left(10^{8} \mathrm{CFU} / \mathrm{ml}\right)$ or $E$. amylovora $\mathrm{Ea} 153\left(10^{7} \mathrm{CFU} / \mathrm{ml}\right)$ in $0.03 \%$ Tween-20 to stigmas with an artist paint brush. Flowers were inoculated late in the day, between 1730 and $1930 \mathrm{~h}$, to limit exposure to sunlight during early bacterial establishment. One exception to this was inoculation between 1500 and 1600 h on 26 April 2007 when the sky was overcast. Treatments were: (i) noninoculated control, (ii) Ea153 applied first date, (iii) Ea153 applied second date, (iv) E325 applied first date, and (v) E325 applied first date followed by Ea153 on second date. Four single-tree replicates were used per treatment in a completely randomized block in 2006, and six replicates were used in 2007.

Flowers were sampled for $\mathrm{pH}$ measurement and for estimation of bacterial population sizes just prior to treatment on the second inoculation date, then again 2 and 4 days later. For each treatment on each tree, 20 flowers were sampled for $\mathrm{pH}$ measurement and 10 flowers were sampled for estimating population sizes. Stigma exudates were extracted as already described, except 20 rather than 50 flowers were combined per 600- $\mu$ sample, and samples were concentrated by $50 \times$ prior to $\mathrm{pH}$ measurement. To determine population size, stigmas of individual flowers were placed, along with stylar tissue, in sterile microcentrifuge tubes containing $1 \mathrm{ml}$ of sterile buffer (10 $\mathrm{mM}$ potassium phosphate, $\mathrm{pH} 7)$. Tubes were vortexed briefly and placed in a sonication bath for $60 \mathrm{~s}$. Samples were again vortexed, and serial dilutions spread on Kings medium B (21) amended with rifampicin $(25 \mu \mathrm{g} / \mathrm{ml})$ and cycloheximide $(50 \mu \mathrm{g} / \mathrm{ml})$ for detection of strain E325 and on CCT medium (defined by Ishimaru and Klos, 13) amended with nalidixic acid $(100 \mu \mathrm{g} / \mathrm{ml})$ for detection of strain Ea153. Dilutions were also spread on NYDA amended with cycloheximide $(50 \mu \mathrm{g} / \mathrm{ml})$ to enumerate indigenous culturable bacteria.

Weather data within the orchard were collected with a WatchDog Data Logger (Model 450; Plainfield, IL). The pH data were subjected to analysis of variance using SAS version 9.1 (SAS Institute, Cary, NC) and means were separated according to least significant difference (LSD) test $(P \leq 0.05)$. A value of zero was assigned to bacterial populations below the detection limit of $10^{2} \mathrm{CFU} /$ flower. Population sizes for each single-tree replicate were averaged before calculating mean and standard error.

Production and assay of antibacterial compound. Observation of inhibition zones on solid PSBM, a medium partially based on sugars and amino acids identified in stigma exudates (33), were followed by attempts to characterize the inhibitory substance. Ingredients of PSBM by weight in 1 liter of water were: $25 \mathrm{~g}$ of glucose, $25 \mathrm{~g}$ of fructose, $0.2 \mathrm{~g}$ of amino acid mix (proline, asparagine, glutamine, and serine in ratio of $3: 2: 2: 1$ ), 
$0.8 \mathrm{~g}$ of $\mathrm{NH}_{4} \mathrm{Cl}, 0.3 \mathrm{~g}$ of $\mathrm{K}_{2} \mathrm{HPO}_{4}, 0.1 \mathrm{~g}$ of $\mathrm{NaH}_{2} \mathrm{PO}_{4}, 0.4 \mathrm{~g}$ of $\mathrm{MgSO}_{4}, 1.2 \mathrm{mg}$ of nicotinic acid, and $15 \mathrm{~g}$ of agar (from SigmaAldrich; St. Louis, MO). To produce the active compound, a 0.1-ml suspension of $P$. agglomerans E325 $\left(10^{8} \mathrm{CFU} / \mathrm{ml}\right.$ in water prepared from NYDA culture) was spread over the entire surface of PSBM in a single plate $(25 \mathrm{ml}$ of medium per standard $9-\mathrm{cm}$ petri plate). After incubation for $24 \mathrm{~h}$ at $28^{\circ} \mathrm{C}$, growth was removed with a razor blade and the agar from one plate was transferred as sections to a $125-\mathrm{ml}$ flask containing $20 \mathrm{ml}$ of water. Noninoculated PSBM agar was similarly transferred as a negative control. The flask was placed on a rotary shaker at 80 rpm for $1 \mathrm{~h}$, and the liquid decanted. The 20-ml water extraction of agar was repeated twice, and the decanted liquid $(\approx 60 \mathrm{ml})$ was pooled and filter sterilized. For partial purification and concentration, $50 \mathrm{ml}$ of crude filtrate was adsorbed onto a C-18 Plus Sep-pak (Waters, Millford, MA), the column was rinsed with $20 \mathrm{ml}$ of water followed by $20 \mathrm{ml} 5 \% \mathrm{MeOH}$, then the active component was eluted with $20 \mathrm{ml} 20 \% \mathrm{MeOH}$. The active fraction was dried in a rotary evaporator after adding $50 \mathrm{ml}$ of isopropyl alcohol, then reconstituted in $500 \mu \mathrm{l}$ water. The crude extract and partially purified material was stored at $4{ }^{\circ} \mathrm{C}$ for up to 7 days or at $-20^{\circ} \mathrm{C}$ for periods up to 8 weeks prior to characterization tests or further purification. Activity assays were performed by pipetting 10 to $12 \mu \mathrm{l}$ of a sample into wells (1.5-mm diameter) in PSBM. After the aqueous sample diffused into the agar (15 to $45 \mathrm{~min}$ ), the medium was overlaid with $4 \mathrm{ml}$ of soft PSBM containing $0.8 \%$ agar inoculated with $100 \mu \mathrm{l}$ of $\approx 10^{9}$ $\mathrm{CFU} / \mathrm{ml}$ of E. amylovora Ea153 (from NYDA culture). The plates were incubated overnight at $28^{\circ} \mathrm{C}$ and then examined for inhibition zones surrounding wells.

Characterization of antimicrobial activity. Crude aqueous agar extract was subjected to varying temperatures, $\mathrm{pH}$ values, and phosphate concentrations before assaying for antibacterial activity as described previously. To test heat stability, the extract was placed in microcentrifuge tubes $(500 \mu \mathrm{l}$ per tube) and exposed for $1 \mathrm{~h}$ to $85,95,105$, and $115^{\circ} \mathrm{C}$, or for $72 \mathrm{~h}$ to $25,30,37$, 50 , and $70^{\circ} \mathrm{C}$. An oven or incubator was used depending on heat treatment, and control samples were held at $4^{\circ} \mathrm{C}$. To test $\mathrm{pH}$ sensitivity, the crude extract, with a $\mathrm{pH}$ between 3.5 and 4.0, was adjusted to $\mathrm{pH}$ values ranging from 2 to 11 with $1 \mathrm{M} \mathrm{HCl}$ or $1 \mathrm{M}$ $\mathrm{NaOH}$, then held for $24 \mathrm{~h}$ at $20^{\circ} \mathrm{C}$ before adjusting to $\mathrm{pH} 7$ and performing the inhibition assay. The effect of phosphate was evaluated by preparing $\mathrm{K}_{2} \mathrm{HPO}_{4}$ and $\mathrm{NaH}_{2} \mathrm{PO}_{4}$ in varying proportions and concentrations and combining the buffer solutions with crude extract $(1: 1, \mathrm{vol} / \mathrm{vol})$. Phosphate levels, thus, were

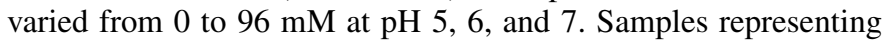
each phosphate/pH treatment were held at $28^{\circ} \mathrm{C}$ for 1,6 , and $18 \mathrm{~h}$ prior to assaying for activity.

Sensitivity of antibacterial activity to amino acids, enzymes, and iron was determined by incubating these substances with the partially purified E325 product (solutions of each were combined $1: 1)$ and then assaying for activity as already described. Each of 20 standard amino acids plus cysteine and hydroxyproline (Amino Acid Standard Kit 22; Pierce, Rockford, IL) were incubated with the antibacterial compound at a concentration of $10 \mathrm{mM}$ for $2 \mathrm{~h}$ at $28^{\circ} \mathrm{C}$. The following enzymes from SigmaAldrich were used: $\beta$-amylase II-B (Catalog No. A7130), bromelain (No. B4882), chymotrypsin (No. C4129), lipase (No. L3001), papain (No. P4762), penicillinase IV (No. P4524), proteinase K (No. P6556), pepsin (No. P7000), and trypsin (No. T303). Solutions of enzymes were prepared with consideration to approximate molecular weight and mass of antibacterial compound and parameter specifications of the manufacturer. Thus, all enzymes were prepared at $1 \mathrm{mg} / \mathrm{ml}$ in partially purified antibiotic solution, except papain was prepared at $10 \mathrm{mg} / \mathrm{ml}$. The $\mathrm{pH}$ was adjusted to 5.0 with $24 \mathrm{mM}$ phosphate buffer, and solutions were incubated for $1.0 \mathrm{~h}$ at $28^{\circ} \mathrm{C}$, with the exception of lipase, which was incubated with antibiotic sample at $37^{\circ} \mathrm{C}$. The effect of iron on antibacterial activity was tested by incorporating $\mathrm{FeCl}_{3}$ at $10 \mathrm{mM}$ and incubating for $2 \mathrm{~h}$ at $28^{\circ} \mathrm{C}$.

The antimicrobial spectrum of the partially purified E325 compound was evaluated by testing the sensitivity of 73 microbial isolates representing 10 genera (Erwinia, Pectobacterium, Pantoea, Enterobacter, Escherichia, Klebsiella, Burkholderia, Pseudomonas, Bacillus, and Microbacterium). To prepare inocula, each strain was initially cultured in $4 \mathrm{ml}$ of nutrient yeast dextrose broth (same as NYDA, but without agar) at $28^{\circ} \mathrm{C}$ and $125 \mathrm{rpm}$ for $24 \mathrm{~h}$. Assay plates were prepared by cutting eight wells in PSBM agar spaced approximately $1.0 \mathrm{~cm}$ apart in a line passing through the plate center. A $10-\mu$ l volume of the partially purified antibacterial product of E325 (obtained using C-18 Plus Sep-pak as already described) was added to each well and allowed to diffuse into the agar. A 1:10 dilution of each test strain was then transferred with loop and spread in a line $(>5.0 \mathrm{~cm}$ long) perpendicular to the row of eight wells and passing directly over one of the wells. E. amylovora Ea153 and P. fluorescens A506 were included on each plate as positive and negative controls, respectively. Plates were incubated at $28^{\circ} \mathrm{C}$ for 48 to $72 \mathrm{~h}$ and then evaluated for inhibition zones extending outward from the wells.

Further purification and characterization of antibacterial compound. For preparative high-performance liquid chromatography (HPLC), $100 \mu \mathrm{l}$ of partially pure extract was injected into a Waters modular HPLC (Milliford, MA) equipped with two Waters 510 binary pumps, a Zorbax ODS $(9.4 \times 250 \mathrm{~mm})$ column, a Waters TCM column heater, and a Waters automated fraction collector. Elution solvents used for a linear gradient were (A) methanol/water/formic acid (50:49.8:0.2, vol/vol) and (B) methanol/water/formic acid (99.8:0:0.2, vol/vol). The flow rate was maintained at $2 \mathrm{ml} / \mathrm{min}$ and the column temperature was $30^{\circ} \mathrm{C}$. Following injection, solvent A comprised the entire flow for 2 min followed by a linear increase of solvent B until $22 \mathrm{~min}$ where it was held for $8 \mathrm{~min}$. One-milliliter fractions were collected within the retention time range of detected activity, i.e., from 10 to $25 \mathrm{~min}$. Activity of the fractions was evaluated and dilution end point of the most active fraction determined by bioassay on PSBM, as already described, prior to characterization using high-performance liquid chromatography-UV/visible-mass spectrometry and analytical thin-layer chromatography (TLC).

Ten-microliter samples of purified fractions were injected into a Series 1100 HPLC system (Agilent Technologies, Palo Alto, CA) equipped with a 5- $\mu \mathrm{m}$ Agilent Hypersil ODS $(4.0 \times 125 \mathrm{~mm})$ reverse-phase column, a G1315B diode array detector (DAD), and a G1946D mass selective detector (MSD), coupled with an atmospheric pressure chemical ionization (APCI) source. Elution solvents used for the linear gradient were (A) methanol/ water/formic acid (0:99.8:0.2, vol/vol) and (B) methanol/water/ formic acid (50:49.8:0.2, vol/vol). The column temperature and mobile phase flow rate were $20^{\circ} \mathrm{C}$ and $0.5 \mathrm{ml} / \mathrm{min}$, respectively. The mobile phase was comprised entirely of solvent A for the initial 2 min after sample injection, followed by a linear gradient of solvent A plus B until reaching $100 \% \mathrm{~B}$ at $20 \mathrm{~min}$, and then remaining entirely solvent $\mathrm{B}$ until $25 \mathrm{~min}$. The DAD continuously monitored and recorded spectra (200 to $700 \mathrm{~nm}$ ) for the entire analysis. The APCI spray chamber conditions were drying gas $\left(\mathrm{N}_{2}\right)$ flow $5 \mathrm{~L} / \mathrm{min}$, drying gas temperature $350^{\circ} \mathrm{C}$, nebulizer pressure $414 \mathrm{kPa}$, vaporizer temperature $425^{\circ} \mathrm{C}$, and coronal discharge $4 \mu \mathrm{A}$. The fragmentor and capillary potentials were 130 and 4,000 V, respectively. The MSD was adjusted to monitor positive ions in the scanning mode, continuously monitoring and recording entire mass spectra within a 100 to $2,500 \mathrm{~m} / \mathrm{z}$ range.

For TLC analysis, lyophilized partially purified extract was dissolved in $1 \mathrm{ml} 90 \%$ methanol, and a $10-\mu \mathrm{l}$ aliquot was adsorbed on Whatman LHPK silica gel 60A plates. Chromatographic separation was carried out in chloroform/methanol/ acetic acid/water $(65: 25: 3: 4, \mathrm{vol} / \mathrm{vol})$ until the solvent front reached $8 \mathrm{~cm}$. Components were visualized using ninhydrin 
reagent, which consisted of $25 \mathrm{ml} 0.2 \%$ (wt/vol) ninhydrin in 1-butanol added to $1 \mathrm{ml} 10 \%$ ( $\mathrm{vol} / \mathrm{vol}$ ) acetic acid in water. Plates sprayed with ninhydrin reagent were dried for $2 \mathrm{~min}$ at $120^{\circ} \mathrm{C}$. Components also were tested for pentoses using Orcin reagent, prepared by dissolving $0.1 \mathrm{~g}$ of 3,5-dihydroxytoluene and $0.05 \mathrm{~g}$ of $\mathrm{FeCl}_{3}$ in $50 \mathrm{ml}$ of $12 \mathrm{~N} \mathrm{HCl}$. Plates were sprayed with Orcin reagent and dried for $5 \mathrm{~min}$ at $150^{\circ} \mathrm{C}$.

\section{RESULTS}

Evaluation of pH on inoculated stigmas. When stigma exudates were extracted from Gala apple blossoms inoculated in the laboratory on different dates, $\mathrm{pH}$ values for extracts were always numerically highest for flowers inoculated with $E$. amylovora strain Ea153 and lowest for flowers inoculated with $P$. agglomerans strain E325. Reduction of extract concentration to volumes that are closer to the original fluid volumes on stigmas revealed even greater differences in $\mathrm{pH}$. On each date, $\mathrm{pH}$ values for the Ea153 treatment were always numerically higher $(\mathrm{pH} 6.5$ to 6.9) than those of the noninoculated control ( $\mathrm{pH} 5.6$ to 6.2), which were always numerically higher than those for E325 (4.8 to 5.1). Analysis of data collected on different dates as replicates showed that the mean of the $\mathrm{pH}$ of concentrated extracts for the three treatments were all different $(P \leq 0.05)$ (Fig. 1).

In the experiment designed to evaluate $\mathrm{pH}$ changes on stigmas in the orchard, weather conditions were typical for central Washington State. Average temperature during the 7-day period from first inoculation to final sampling was $14.0^{\circ} \mathrm{C}$ in 2006 and $13.8^{\circ} \mathrm{C}$ in 2007 . No precipitation occurred and little or no vegetative wetness was recorded. Results indicated a similar trend to that indicated in the laboratory; however, statistical differences $(P \leq 0.05)$ were indicated only for the final sampling date in 2007 (Fig. 2). Mean $\mathrm{pH}$ values for samples increased over time and were in a narrower range (between 5.0 and 5.8 overall, or within $0.4 \mathrm{pH}$ units on any sampling date) than those of the laboratory test. Populations of bacteria applied to flowers were at the expected levels (Fig. 3) and preinoculation of stigmas with strain E325 resulted in lower populations of E. amylovora. With the detection limit at $10^{2} \mathrm{CFU} /$ flower, indigenous culturable organisms were detected at $\log \mathrm{CFU}$ of $<3.0$ on fewer than $30 \%$ of control blossoms.

Characterization of antimicrobial activity. When 10 to $12 \mu \mathrm{l}$ of crude extract from solid PSBM culture of strain E325 was

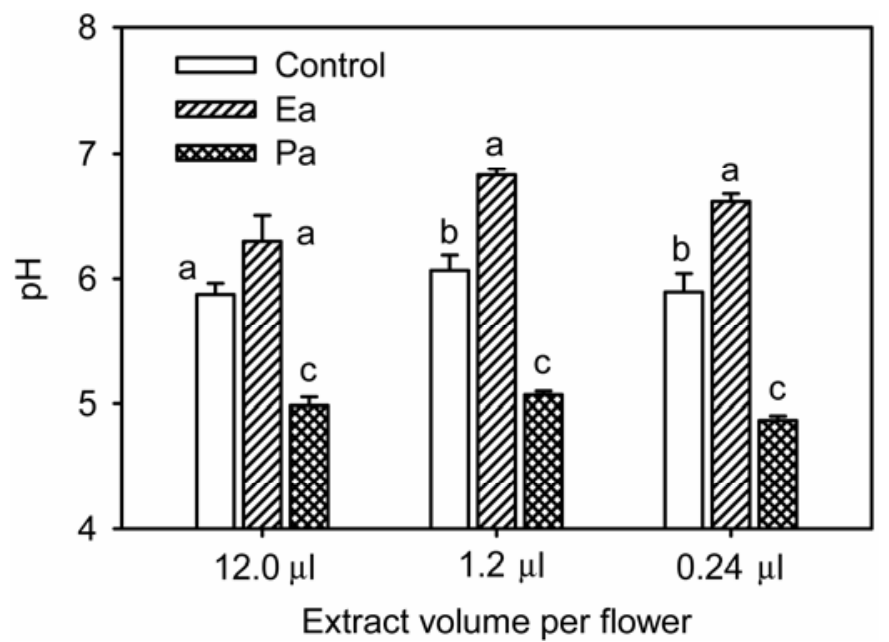

Fig. 1. Effect of Pantoea agglomerans E325 (Pa) and Erwinia amylovora Ea153 (Ea) on $\mathrm{pH}$ of Gala apple stigmas in laboratory inoculations, as determined by measuring $\mathrm{pH}$ in extracted exudates. The detached flowers were inoculated and incubated at $24^{\circ} \mathrm{C}$ for $24 \mathrm{~h}$ prior to extraction. Vertical lines represent standard error. Within each bar group, means with unlike letters were different according to least significant difference $(P \leq 0.05)$. applied to wells cut in PSBM agar and overlaid with a soft agar suspension of $E$. amylovora, clear inhibition zones typically 10 to $12 \mathrm{~mm}$ in diameter resulted; no inhibition was observed with extracts from noninoculated PSBM agar. Crude extract samples subjected to various temperatures for $1 \mathrm{~h}$ retained activity at 85 , 95 , and $105^{\circ} \mathrm{C}$, but not at $115^{\circ} \mathrm{C}$; samples held for $72 \mathrm{~h}$ retained activity at $25,30,37$, and 50 , but not at $70^{\circ} \mathrm{C}$. Adjustment of $\mathrm{pH}$ of the extract to values from 2 to 11 , followed by a 24-h incubation and then readjustment to neutral $\mathrm{pH}$ prior to bioassay, showed that there was no change in inhibitory activity when extract was held at $\mathrm{pH}$ range from 2 to 7 , but inactivation resulted from exposure to $\mathrm{pH}$ values from 8 to 11 . Inactivation under alkaline conditions was not reversed even when readjusted to acid conditions ( $\mathrm{pH}$ between 3 and 6). When phosphate concentration was increased from 2.4 to $96 \mathrm{mM}$, and $\mathrm{pH}$ and incubation period also were varied, inhibitory activity remained stable at $\mathrm{pH} 5$. At $\mathrm{pH} 6$ after $18 \mathrm{~h}$, activity was stable in the presence of 0 to $6 \mathrm{mM}$ phosphate, but diminished when phosphate concentrations were at 12 to $96 \mathrm{mM}$ (Fig. 4). At pH 7, activity was undetectable after $6 \mathrm{~h}$ in solutions of 24 to $96 \mathrm{mM}$ phosphate, and only slightly detectable after $18 \mathrm{~h}$ in $2.4 \mathrm{mM}$ phosphate. Activity of the partially purified E325 product toward E. amylovora was unaffected by the addition of amino acids, selected enzymes, or iron. Of $73 \mathrm{mi}-$ crobial isolates tested for sensitivity to the E325 compound, only the 27 isolates of E. amylovora tested were sensitive (Table 1). Bacteria representing Erwinia rhapontici and seven other species in Enterobacteriaceae were not inhibited by the compound.
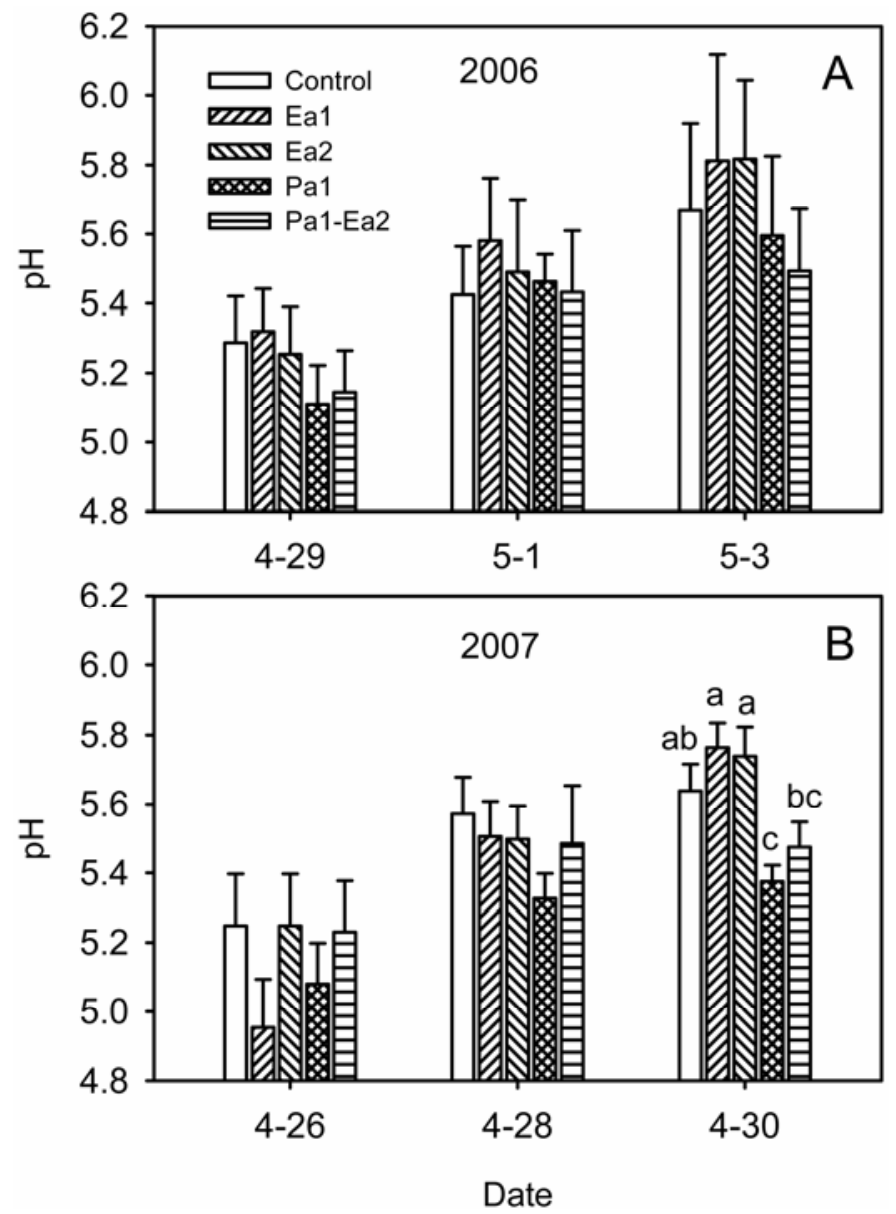

Fig. 2. Effect of Pantoea agglomerans E325 (Pa) and Erwinia amylovora Ea153 (Ea) on pH of Gala apple stigmas in field inoculations in A, 2006 and B, 2007 as determined by measuring $\mathrm{pH}$ in extracted exudates. Inoculations were performed on two dates ( 1 and 2 in key), i.e., 2 days before the first sampling shown and a few hours after first sampling. Vertical lines represent standard error. Means with unlike letters were different according to least significant difference $(P \leq 0.05)$. 
Nonenteric bacteria in the genera Burkholderia, Pseudomonas, Bacillus, and Microbacterium were likewise unaffected.

Further purification and characterization of antibacterial compound. Analyses of the purified active substance yielded a single total ion chromatogram peak (Fig. 5A). The UV-vis signal in the monitored range was weak and indicated, in conjunction with the TIC, that no other peaks were associated within the active fractions. Peaks from active fractions had mass spectra with prominent peaks at $556 \mathrm{~m} / \mathrm{z}$ (Fig. 5B), indicating a molecular weight of approximately 555. Dilution-end-point assays with material derived from active fractions indicated inhibitory activity toward E. amylovora with a minimum of 20 to $40 \mathrm{ng}$ of the purified compound (or approximately 3.6 to $7.2 \mu \mathrm{M}$ concentration in $10 \mu \mathrm{l}$ added to agar well). Following TLC, reaction with ninhydrin reagent produced a reddish blue band at $\mathrm{Rf}=0.3$, revealing the presence of free amines. Orcin reagent did not react, thus sugar residues were not detected in the purified preparation.

\section{DISCUSSION}

Early fire blight researchers hypothesized based on in vitro studies that bacterial antagonists inhibit E. amylovora by producing acid $(11,12,35)$, but workers now generally believe competitive exclusion and antibiotic production are the main mechanisms of antagonism on blossoms $(17,43)$. Prior to the current study, $\mathrm{pH}$ modification by bacteria on flower stigmas, the primary site of epiphytic establishment by the pathogen, had not been evaluated. Under ideal laboratory conditions for bacterial colonization of flowers, we found that $P$. agglomerans strain E325
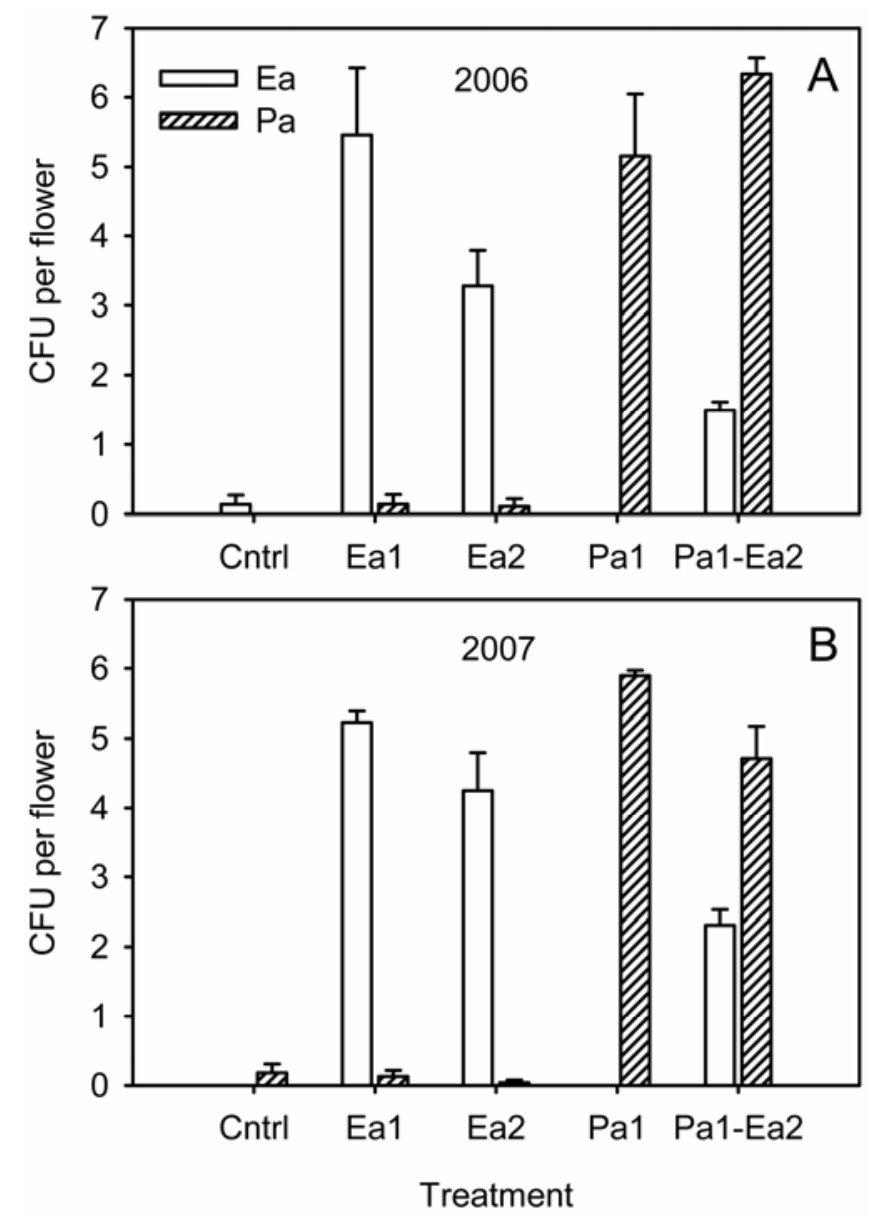

Fig. 3. Population size of Pantoea agglomerans E325 (Pa) and Erwinia amylovora Ea153 (Ea) on Gala apple stigmas in field experiment in A, 2006 and B, 2007 designed for evaluating bacterial modification of $\mathrm{pH}$. Data are presented for the final sampling date. Vertical lines represent standard error. exhibited a capacity to reduce the $\mathrm{pH}$ on stigmas to levels that could reduce growth of E. amylovora. Conversely, an increase in $\mathrm{pH}$ was observed on flowers inoculated with E. amylovora alone and was comparable to previous results with pear fruit tissue inoculated with the pathogen (51). A similar trend was indicated in the field on the final sampling date, with mean $\mathrm{pH}$ values numerically higher for pathogen-inoculated flowers and lower for the antagonist-inoculated flowers. However, statistical differences were shown only in 2007, when the $\mathrm{pH}$ for antagonist-inoculated flowers, whether they were challenged with E. amylovora or not, was slightly lower $(P \leq 0.05)$ than treatments with the pathogen alone. These results did not implicate $\mathrm{pH}$ modification as an important mode of antagonism toward E. amylovora, but the possibility still exists that increased acidity caused by E325 may reduce the growth rate of E. amylovora, thereby contributing to antagonism and suppression of the pathogen. The optimum $\mathrm{pH}$ for E. amylovora is between 6 and 7 or higher (42) and $\mathrm{pH}$ values below 6.0 have been shown to reduce growth $(12,51)$. It is questionable, however, whether $\mathrm{pH}$ in extracts from flowers was representative of the $\mathrm{pH}$ of the intercellular spaces on stigmas where bacteria reside and not artifactual, so conclusions related to stigma $\mathrm{pH}$ must await the development and application of more direct methods of $\mathrm{pH}$ measurement on stigmas.

If $\mathrm{pH}$ in exudates extracted from orchard blossoms reflects approximate hydrogen ion concentrations on stigmatic surfaces, the data indicate a $\mathrm{pH}$ range (between 5 and 6) conducive for strain E325 to inhibit E. amylovora through antibiosis as demonstrated in vitro. Strong antibacterial activity was shown under acid or neutral $\mathrm{pH}$. The activity became unstable at $\mathrm{pH} 6$ or 7 when

\section{Phosphate concentration (mM)}

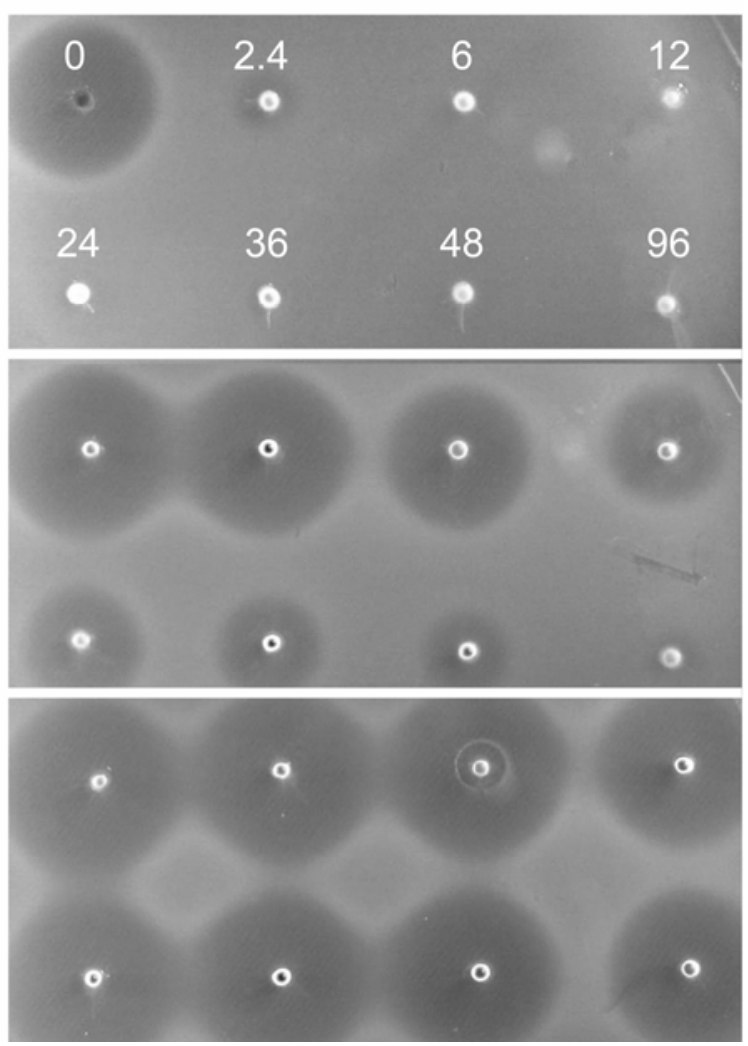

Fig. 4. Results of assays in which phosphate concentration in crude antibacterial extract from culture of Pantoea agglomerans E325 grown on partial stigma-based medium (PSBM) was increased by $0,2.4,6$, and $12 \mathrm{mM}$ (top row of each panel) or $24,36,48$, and $96 \mathrm{mM}$ (bottom row of each panel) at varying $\mathrm{pH}$ (left); concentrations are shown in top panel only. Solutions were incubated at $28^{\circ} \mathrm{C}$ for $18 \mathrm{~h}$ before assaying for activity in PSBM-agar wells overlaid with agar suspension of Erwinia amylovora Ea153. 
phosphate was increased beyond the initial level in PSBM $(2.4 \mathrm{mM})$, and quickly disappeared at $\mathrm{pH} 8$ even under low phosphate conditions. It is not known whether production of the E325 antibiotic is $\mathrm{pH}$ dependent. The antibiotic was produced under neutral to acidic conditions in low phosphate media, but production under alkaline conditions would not be detected in our assays because the antibiotic activity is irreversibly eliminated after exposure to basic $\mathrm{pH}$ conditions.

The phosphate concentration in PSBM was below that of most media used by researchers to test strains of $P$. agglomerans for production of antibiotics inhibitory to E. amylovora $(20,46$, 50,53). For instance, Wodzinski et al. (50) tested 346 putative strains of $P$. agglomerans on a glycerol-ammonium medium containing approximately $100 \mathrm{mM}$ phosphate. Conversely, a glucose-asparagine medium used by Ishimaru et al. (14) for antibiotic production by $P$. agglomerans strain C9-1 contained only $1.3 \mathrm{mM}$ phosphate and was buffered to neutrality with morpholino-propane sulfonic acid. Strain E325 did not inhibit $E$. amylovora on this medium (P. L. Pusey, unpublished data), perhaps because the buffering by morpholino-propane sulfonic acid (initially $\mathrm{pH}$ 7.4) prevents the development of acidic conditions required for consistent antibiosis in the bioassay. Phosphates can regulate antibiotic production by some microorganisms, suppressing biosynthesis when concentrations are above $10 \mathrm{mM}$ (25); in our study with E325, however, we demonstrated that phosphate deactivated an antibacterial compound after it was produced. Although phosphates are transported in plants and detected in xylem exudates (5), it is unknown whether they are present in

TABLE 1 . Sensitivity of microbial strains to inhibitory activity of the isolated compound produced by Pantoea agglomerans E325 in partial stigma-based medium

\begin{tabular}{|c|c|c|c|}
\hline \multirow[b]{2}{*}{ Indicator species ${ }^{\mathrm{a}}$} & \multirow[b]{2}{*}{ Isolate source $^{\mathrm{b}}$} & \multicolumn{2}{|c|}{ No. of isolates } \\
\hline & & $\begin{array}{c}\text { Total } \\
\text { tested }\end{array}$ & Sensitive \\
\hline Erwinia amylovora & $\mathrm{J}, \mathrm{Mc}, \mathrm{P} 8, \mathrm{R} 15, \mathrm{Su}, \mathrm{T}$ & 27 & 27 \\
\hline Erwinia rhapontici & $\mathrm{S}$ & 1 & 0 \\
\hline Pectobacterium carotovora & S3 & 3 & 0 \\
\hline Pantoea agglomerans & $\mathrm{B} 2, \mathrm{I}, \mathrm{P} 7, \mathrm{R} 2, \mathrm{~S} 3, \mathrm{~T} 2$ & 17 & 0 \\
\hline Pantoea ananatis & $\mathrm{T}$ & 1 & 0 \\
\hline Enterobacter cloacae & $\mathrm{Mc}$ & 1 & 0 \\
\hline Enterobacter hormaechei & $\mathrm{P}$ & 1 & 0 \\
\hline Escherichia coli & G & 1 & 0 \\
\hline Klebsiella pneuтопiae & $\mathrm{Mc}$ & 1 & 0 \\
\hline Burkholderia cepacia & A25416 & 1 & 0 \\
\hline Pseudomonas aureofaciens & A15926 & 1 & 0 \\
\hline Pseudomonas fluorescens & A13525,A17518, L,M,P,S & 6 & 0 \\
\hline Pseudomonas putida & A12633,A17470, M2 & 4 & 0 \\
\hline Pseudomonas syringae & $\mathrm{P}$ & 1 & 0 \\
\hline Bacillus pumilus & $\mathrm{P}$ & 1 & 0 \\
\hline Bacillus subtilis & M, P3 & 4 & 0 \\
\hline Microbacterium sp. & $\mathrm{P} 2$ & 2 & 0 \\
\hline
\end{tabular}

a Identification, unless established in literature or by American Type Culture Collection (ATCC; Manassas, VA) was determined using at least two methods: (i) fatty acid methyl ester analysis with Microbial Identification System (Microbial ID, Inc., Newark, DE), and (ii) 16S rRNA gene sequence analysis (1). In addition to ATCC strains, isolates previously referred to in the literature are E. amylovora Ea153 (18,19); Pantoea agglomerans strains C9-1 (14,19), Eh252 (46), and Eh318 (7,53); E. coli C600-2Sm (28); and Pseudomonas fluorescens A506 $(18,23)$.

${ }^{\mathrm{b}}$ Isolates were obtained from S. V. Beer (B), K. Geider (G), C. A. Ishumaru (I), K. B. Johnson (J), S. E. Lindow (L), M. Mazzola (M), R. J. McLaughlin (Mc), P. L. Pusey (P), R. G. Roberts (R), V. O. Stockwell (S), G. W. Sundin $(\mathrm{Su})$, and T. N. Temple (T). When more than one isolate was obtained from the same source, the letter(s) representing source is followed by number of isolates. ATCC strains are indicated with "A" followed by the ATCC number. All isolates of E. amylovora came from apple or pear in Washington or Oregon, except one isolate from apple in Michigan (Su). All other bacteria were from pome orchard environments, mostly aerial plant parts, with the exception of Escherichia coli, Pectobacterium carotovora, and ATCC strains. stigma exudates or occur at levels that may affect the antibiotic synthesis or activity of E325.

The antibacterial activity of the E325 product has so far exhibited characteristics distinguishing it from other antibiotics of P. agglomerans that are inhibitory to E. amylovora $(10,17,43)$. Unlike many antibiotics of this group, activity of the E325 compound was unaffected by amino acids. Wodzinski and Paulin (50) found that all but six of a group of 90 strains of $P$. agglomerans produced antibiotics that were inactivated by certain amino acids, and distinguished 13 antibiotic classes based on amino acid sensitivity. Antibiosis in their study was most commonly reversed by histidine. The antibiotic activity of E325 also was unaffected by enzymes reported to inactivate some antibiotics of $P$. agglomerans. For example, unlike the E325 compound, the antibiotic of strain Eh252 was inactivated by proteases (46). The high specificity of the E325 compound to E. amylovora is notable, given that other antibiotics of $P$. agglomerans have reportedly shown a broader spectrum of activity $(14,20,46,53)$ affecting other enteric bacteria and frequently also nonenteric bacteria. The specificity of the antibiotic of E325 to E. amylovora may be advantageous for incorporating E325 in mixtures of complementary antagonists, an approach proposed for maximizing biological control of fire blight (17). Other unique properties of the E325 antibiotic include its inactivity above $\mathrm{pH} 7$ and its instability in the presence of high phosphate levels. The sensitivity to phosphate at concentrations typically used in media for antibiosis assays likely explains why antibiosis due to E325 was previously undetected or inconsistent. These findings are congruous with
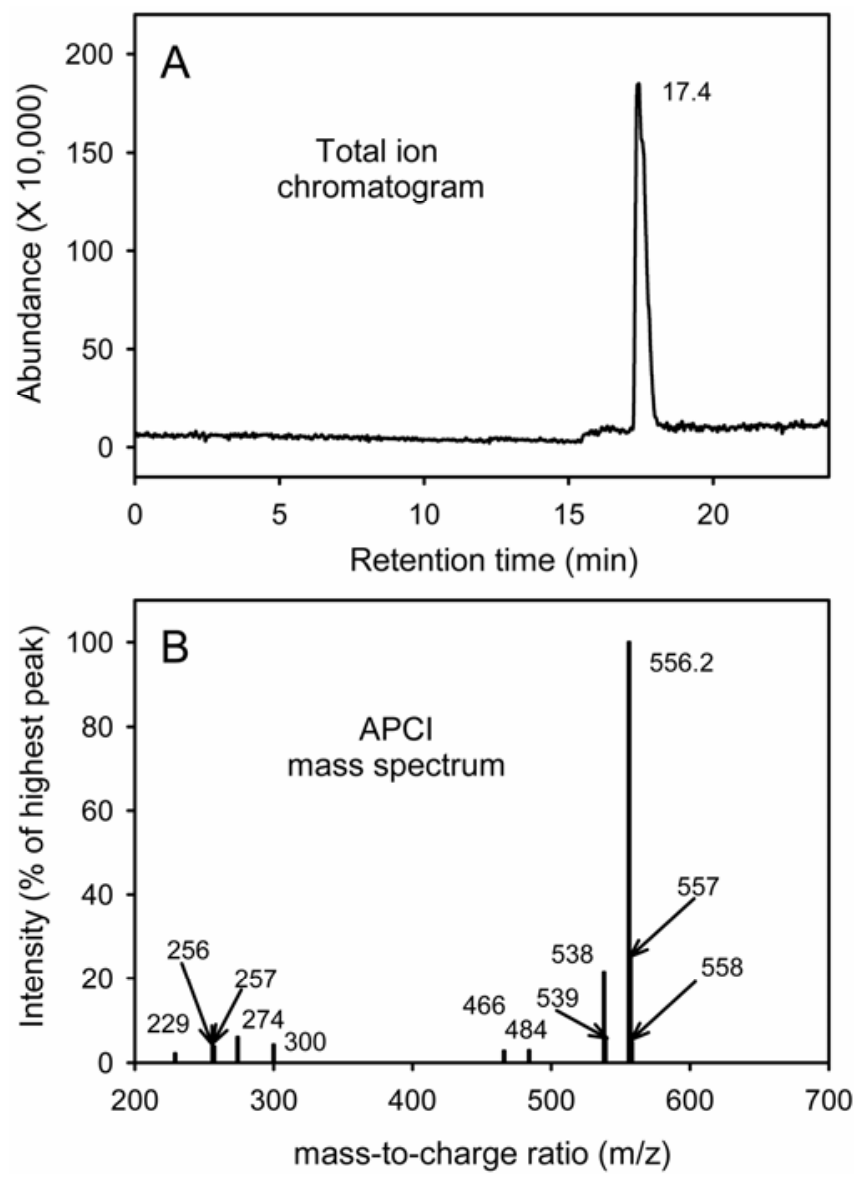

Fig. 5. Results of liquid chromatography-UV/visible-mass spectrometry analysis presented as $\mathbf{A}$, total ion chromatogram indicating single peak at retention time also yielding a fraction from culture of Pantoea agglomerans strain E325 highly inhibitory to Erwinia amylovora and B, positive atmospheric pressure chemical ionization (APCI) mass spectra of inhibitory compound produced by E325. Arrows indicate top of bars conjoined to other bars. 
recent polymerase chain reaction (PCR) analyses of strain E325 that failed to detect paaB (V. O. Stockwell, unpublished data), a gene in the operon for synthesis of pantocin A (15), a common antibiotic of strains of $P$. agglomerans with efficacy against fire blight.

Two separate data sets, one dealing with $\mathrm{pH}$ on the stigma and the other with antibiotic production in a partial stigma-based medium, were not shown to be directly related, but both have possible implications in biological control of fire blight with $P$. agglomerans strain E325. Analysis of exudates from inoculated stigmas indicated that strain E325 may lower the $\mathrm{pH}$ on stigmas, which to some degree, may reduce growth of E. amylovora. Secondly, assuming $\mathrm{pH}$ values are close to those actually occurring on flower stigmas, results indicate a $\mathrm{pH}$ range on the stigma favorable for antibiotic activity, which was found in vitro to be $\mathrm{pH}$ sensitive. Work is in progress to further investigate acidification and antibiosis and their possible roles and interrelationship in the suppression of E. amylovora by $P$. agglomerans E325 on stigmatic surfaces of apple and pear.

\section{ACKNOWLEDGMENTS}

We thank J. Duffy and D. Buchanan for outstanding technical support, and Van Well Nursery for providing trees.

\section{LITERATURE CITED}

1. Amann, R. I., Ludwig, W., and Schleifer, K. H. 1995. Phylogenetic identification and in situ detection of individual microbial cells without cultivation. Microbiol. Rev. 59:143-169.

2. Andrews, J. H. 1985. Strategies for selecting antagonistic microorganisms from the phylloplane. Pages 31-44 in: Biological Control on the Phylloplane. C. Windels and S. E. Lindow, eds. The American Phytopathological Society, St. Paul, MN.

3. Ark, P. A., and Hunt, M. L. 1941. Saprophytes antagonistic to phytopathogenic and other microorganisms. Science 93:354-355.

4. Beer, S. V., and Rundle, J. R. 1983. Suppression of Erwinia amylovora by Erwinia herbicola in immature pear fruits. (Abstr.) Phytopathology 73:1346.

5. Bieleski, R. L. 1973. Phosphate pools, phosphate transport and phosphate availability. Annu. Rev. Plant Physio. 49:447-454.

6. Billing, E. 2000. Fire blight risk assessment systems and models. Pages 235-252 in: Fire Blight: The Disease and Its Causative Agent, Erwinia amylovora. J. L. Vanneste, ed. CAB International, Wallingford, UK

7. Brady, S. F., Wright, S. A., Lee, J. C., Sutton, A. E., Zumoff, C. H., Wodzinski, R. S., Beer, S. V., and Clardy, J. 1999. Pantocin B, an antibiotic from Erwinia herbicola discovered by heterologous expression of cloned genes. J. Am. Chem. Soc. 121:11912-11913.

8. Environmental Protection Agency, Biopesticides and Pollution Division. 2006. Pantoea agglomerans strain C9-1; exemption from the requirement of a tolerance. EPA, Washington, DC. Federal Register 71(80):2459024596.

9. Environmental Protection Agency, Biopesticides and Pollution Division. 2006. Pantoea agglomerans strain E325; exemption from the requirement of a tolerance. EPA, Washington, DC. Federal Register 71(182):5492854933.

10. Epton, H. A. S., Wilson, M., Nicholson, S. L., and Sigee, D. C. 1994. Biological control of Erwinia amylovora with Erwinia herbicola. Pages 335-352 in: Ecology of Plant Pathogens. J. P. Blakeman and B. Williamson (eds.). CAB International, Wallingford, UK.

11. Farabee, G. J., and Lockwood, J. L. 1958. Inhibition of Erwinia amylovora by Bacterium sp. isolated from the fire blight cankers. Phytopathology 48:209-211.

12. Goodman, R. N. 1965. In vitro and in vivo interactions between components of mixed bacterial cultures isolated from apple buds. Phytopathology 55:217-221.

13. Ishimaru, C., and Klos, E. J. 1984. New medium for detecting Erwinia amylovora and its use in epidemiological studies. Phytopathology 74:1342-1345.

14. Ishimaru, C. A., Klos, E. J., and Brubaker, R. R. 1988. Multiple antibiotic production by Erwinia herbicola. Phytopathology 78:746-750.

15. Jin, M., Wright, S. A. I., Beer, S. V., and Clardy, J. 2003. The biosynthetic gene cluster of pantocin A provides insights into biosynthesis and a tool for screening. Angew. Chem. Int. Edit. 42:2902-2905.

16. Johnson, K. B., and Stockwell, V. O. 1998. Management of fire blight: A case study in microbial ecology. Annu. Rev. Phytopathol. 36:227-248.
17. Johnson, K. B., and Stockwell, V. O. 2000. Biological control of fire blight. Pages 319-337 in: Fire Blight: The Disease and Its Causative Agent, Erwinia amylovora. J. L. Vanneste (ed.). CAB International, Wallingford, UK.

18. Johnson, K. B., Stockwell, V., Burgett, O. D., Sugar, D., and Loper, J. E. 1993. Dispersal of Erwinia amylovora and Pseudomonas fluorescens by honey bees from hives to apple and pear blossoms. Phytopathology 83:478-484.

19. Johnson, K. B., Stockwell, V. O., McLaughlin, R. J., Sugar, D., Loper, J. E., and Roberts, R. G. 1993. Effect of antagonistic bacteria on establishment of honey bee-dispersed Erwinia amylovora in pear blossoms and on fire blight control. Phytopathology 83:995-1002.

20. Kearns, L. P., and Hale, C. N. 1996. Partial characterization of an inhibitory strain of Erwinia herbicola with potential as a biocontrol agent for Erwinia amylovora, the fire blight pathogen. J. Appl. Bacteriol. 81:369-374.

21. King, E. O., Ward, M. K., and Raney, D. E. 1954. Two simple media for the demonstration of pyocyanin and fluorescin. J. Lab. Clin. Med. 44:301307.

22. Lindow, S. E. 1985. Integrated control and role of antibiosis in biological control of fire blight and frost injury. Pages 83-115 in: Biological Control on the Phylloplane. C. Windels and S. E. Lindow, eds. The American Phytopathological Society, St. Paul, MN.

23. Lindow, S. E., McGourty, G., and Elkins, R. 1996. Interactions of antibiotics with Pseudomonas fluorescens strain A506 in the control of fire blight and frost injury to pear. Phytopathology 86:841-848.

24. Loper, J. E., Henkels, M. D., Roberts, R. G., Grove, G. G., Willet, M. J., and Smith, T. J. 1991. Evaluation of streptomycin, oxytetracycline, and copper resistance of Erwinia amylovora isolated from pear orchards in Washington State. Plant Dis. 75:287-290.

25. Martin, J. F., and Demain, A. L. 1980. Control of antibiotic biosynthesis. Microbiol. Rev. 44:230-251.

26. McManus, P. S., and Jones, A. L. 1994. Epidemiology and genetic analysis of streptomycin-resistant Erwinia amylovora from Michigan and evaluation of oxytetracycline for control. Phytopathology 84:627-633.

27. Mercier, J., and Lindow, S. E. 1996. A method involving ice nucleation for the identification of microorganisms antagonistic to Erwinia amylovora pear flowers. Phytopathology 86:940-945.

28. Metzger, M., Bellemann, P., Schwartz, T., and Geider, K. 1992. Sitedirected and transposon-mediated mutagenesis with pfd-plasmids by electroporation of Erwinia amylovora and Escherichia coli cells. Nucleic Acids Res. 20:2265-2270.

29. Pusey, P. L. 1997. Crab apple blossoms as a model for research on biological control of fire blight. Phytopathology 87:1096-1102.

30. Pusey, P. L. 1999. Laboratory and field trials with selected microorganisms as biocontrol agents for fire blight. Acta Hort. 489:655-661.

31. Pusey, P. L. 2002. Biological control agents for fire blight of apple compared under conditions limiting natural dispersal. Plant Dis. 86:639644.

32. Pusey, P. L., and Curry, E. A. 2004. Temperature and pomaceous flower age related to colonization by Erwinia amylovora and antagonists. Phytopathology 94:901-911.

33. Pusey, P. L., Rudell, D. R., Curry, E. A., and Mattheis, J. P. 2008. Characterization of stigma exudates in aqueous extracts from apple and pear flowers. HortScience 43:1471-1478.

34. Psallidas, P. G., and Tsiantos, J. 2000. Chemical Control of Fire Blight. Pages 199-234 in: Fire Blight: The Disease and Its Causative Agent, Erwinia amylovora. J. L. Vanneste, ed. CAB International, Wallingford, UK.

35. Riggle, J. H., and Klos, E. J. 1972. Relationship of Erwinia herbicola to Erwinia amylovora. Can. J. Bot. 50:1077-1083.

36. Sleesman, J. P., and Leben, C. 1978. Preserving phytopathogenic bacteria at $-70^{\circ} \mathrm{C}$ or with silica gel. Plant Dis. Rep. 62:910-913.

37. Steinwand, B., and Brohm, M. 2006. Joint review of microbials, and pheromones and "other" biopesticides. Project Sheet of Risk Reduction Subcommittee of NAFTA Technical Working Group on Pesticides, Project ID RR04-99-1105.

38. Stessel, G. J., Leben, C., and Keitt, G. W. 1953. Screening tests designed to discover antibiotics suitable for plant disease control. Mycologia 45:325-334.

39. Stockwell, V. O., Johnson, K. B., and Loper, J. E. 1996. Compatibility of bacterial antagonists of Erwinia amylovora with antibiotics used to control fire blight. Phytopathology 86:834-840.

40. Tewoldemedhin, Y. T., Lamprecht, S. C., McLeod, A., and Mazzola, M. 2006. Characterization of Rhizoctonia spp. recovered from crop plants used in rotational cropping systems in the Western Cape province of South Africa. Plant Dis. 90:1399-1406.

41. Thomson, S. V. 1986. The role of the stigma in fire blight infections. Phytopathology 76:476-482.

42. Van der Zwet, T., and Keil, H. L. 1979. Fire blight: Bacterial disease of 
rosaceous plants. U.S. Dep. Agric., Sci. Educ. Admin., Agric. Handb. 510.

43. Vanneste, J. L. 1996. Honey bees and epiphytic bacteria to control fire blight, a bacterial disease of apple and pear. Biocontrol News Information $17: 67 \mathrm{~N}-78 \mathrm{~N}$.

44. Vanneste, J. L. (ed.) 2000. Fire Blight: The Disease and Its Causative Agent, Erwinia amylovora. CAB International, Wallingford, UK.

45. Vanneste, J. L., Cornish, D. A., Yu, J., and Voyle, M. D. 2002. P10c: A new biological control agent for control of fire blight which can be sprayed or distributed using honey bees. Acta Hort. 590:231-235.

46. Vanneste, J. L., Yu, J., and Beer, S. V. 1992. Role of antibiotic production by Erwinia herbicola Eh252 in biological control of Erwinia amylovora. J. Bacteriol. 174:2785-2796.

47. Vanneste, J. L., Yu, J., Harper, G. E., and Perry, J. H. 1996. Plugs of immature pear fruit to assess the virulence of Erwinia amylovora and to study in the laboratory the interaction between biological control agents and the fire blight pathogen. Acta Hort. 411:303-307.

48. Wilson, M., Epton, H. A. S., and Sigee, D. C. 1990. Biological control of fire blight of hawthorn (Crataegus monogyna) with Erwinia herbicola under protected conditions. Plant Pathol. 39:301-308.

49. Wilson, M., Epton, H. A. S., and Sigee, D. C. 1992. Biological control of fire blight of hawthorn (Crataegus monogyna) with fluorescent Pseudomonas spp. under protected conditions. J. Phytopathol. 136:16-26.

50. Wodzinski, R. S., and Paulin, J. P. 1994. Frequency and diversity of antibiotic production by putative Erwinia herbicola strains. J. Appl. Bacteriol. 76:603-607.

51. Wodzinski, R. S., Umholtz, T. E., Rundle, J. R., and Beer, S. V. 1994. Mechanisms of inhibition of Erwinia amylovora by E. herbicola in vitro and in vivo. J. Appl. Bacteriol. 76:22-29.

52. Wrather, J. A., Kuc, J., and Williams, E. B. 1973. Protection of apple and pear fruit tissue against fire blight with nonpathogenic bacteria. Phytopathology 63:1075-1076.

53. Wright, S. A. I., Zumoff, C. H., Schneider, L., and Beer, S. V. 2001. Pantoea agglomerans strain Eh318 produces two antibiotics that inhibit Erwinia amylovora in vitro. Appl. Environ. Microbiol. 67:284-292. 